Egypt. Acad. J. Biolog. Sci., 5 (2): 15 -20 (2013)

Email: egyptianacademic@yahoo.com

Received: 25 / 4 / 2013
F. Toxicology \&Pest control

ISSN: 2090 - 0791

www.eajbs.eg.net

\title{
Influence of some plant extracts on Varroa mite and performance of honey bee Apis mellifera colonies
}

\author{
Al-Zarog, A. A. and El-Bassiouny, A. M. \\ Zoology, Dept., Fac. of Science, Sebha Univ., Sebha, Lybia
}

\begin{abstract}
Nowadays the ectoparasite mite, Varroa jacobsoni still a serious problem affecting apiculture among Lybian beekeepers. Recently, the alternative control based on natural products extracted from medicinal and ornamental plants as control agents for the Varroa mite considered more save to human being and bees. plant extract of Thyme, mixture of Fenugreek \& Santonica, Fenugreek alone and Santonica alone were evaluated against Varroa mite at the apiaries located at Sebha, Lybia during (March - April), 2012.

The data clearly show that, an increased the efficiency of any extracts used for Varroa control with the superiority of Thyme followed by mixture of Fenugreek \& Santonica, Fenugreek alone and finally Santonica alone. This extracts caused an obvious reduction of the rate of infestation either in the sealed brood or on the adult bees, moreover increase in the number of sealed worker brood cells and, lastly, an increase in the number of combs covered from both sides with adult worker bees (colony strength) in the treated colony.
\end{abstract}

Keywords: Honey bee, Apis mellifera, Varroa mite, Thyme, Santonica, Fenugreek

\section{INTRODUCTION}

Nowadays the ectoparasite mite, Varroa jacobsoni (Oud) still a serious problem affecting apiculture among Egyptian beekeepers. It caused damage to individual bees that emerge from infested brood cells. At high levels of Varroa infestation, there is a rapid decline in the number of adult bees, severe damage to the brood and death of the colony usually occur, (Elbassiouny et $a l, 2004)$. Also at high infestation level, bees have reduced their life span (Elbassiouny, 1998). The mites also feed on adults between reproductive periods in brood. Their feeding leads to the possible spread of viral pathogens (Sammataro, 1997) and bacteria (Glinski and Jarose, 1992). These various effects of feeding lead to a complex of symptoms due to a parasitic mite syndrome (Shimanuki et al., 1994), which proved as a sudden loss in number of worker bees in a colony and subsequent death of the colony. The main method of protection against varroa mite is the use of acaricides (Eischen, 1998), but the repeated treatment strategy induced resistance in $V$. jacobsoni to acaricides (Colin et al., 1997; Pettis et al., 1998 and Elbassiouny, 2003). Moreover, contamination hive products were occurs, which harmful for human health (Wallner, 1995).

Therefore, the present study aimed to find out alternative control strategies based on natural products extracted from medicinal and ornamental plants as control agents for the Varroa mite.

\section{MATERIAL AND METHODS}

The present work was conducted at the apiaries located at Sebha, Lybia during (March-April), 2012. Twenty-five colonies, headed with natural mated local Carnica queens (Apis mellifera carnica), were divided into five groups (four experimental and the last one was left untreated as control), each group consisting of five colonies nearly equal in 
their strength which contain only combs covered with adult worker bees and the surplus combs were removed, therefore colonies were comprised the actually occupied number of combs to reduce the colony space.

Plant extracts from fenugreek, santonica and theme were used for this study. One kilogram of each tested material was tested, they were heated in an equal volume of distilled water and placed overnight. An amount of $100 \mathrm{ml}$ from each extract (the mixture of fenugreek and santonica was prepared by mixing equal parts of each extracts of them) were applied. Each amount (100 $\mathrm{ml}$ ) was used by two ways: the first (50 $\mathrm{ml}$ ), sprayed on the frames covered with bees and the hive cavity and the second $(50 \mathrm{ml})$ added to the sugar syrup offered to the tested colonies. Each plant extract was applied four times at four-day intervals. All experimental colonies received sugar syrup (50\%) two times weekly, immediately before the beginning of the application and every week after the application and normal beekeeping.

The colonies were examined before and after treatment to determine the effect of these treatments on:

1- Varroa mite infestation levels which estimated in both adult bees and sealed brood before the treatment and after each application. The infestation level of adult honey bees was estimated according to the method described by Shimanuki and Knox (2000). The infestation level of
Varroa mite in brood was estimated by opening 10 sealed worker brood cells using forceps and counting adult varroa mite.

2- Colony vigor which measured by counting the worker sealed broods at 13day interval and number of combs covered from both sides with adult bees as colony strength.

\section{RESULTS AND DISCUSSION}

Plant extract of Thyme, mixture of Fenugreek \& Santonica, Fenugreek alone and Santonica alone were examined in experimental honeybee colonies to determine the effect of these treatments on the following parameters

\section{Worker brood infestation with $V$. jacobsoni}

The rate of honeybee sealed worker brood infestation with Varroa mite in the experimental colonies just before treatments ranged between 10.2 $13.1 .0 \%$. Treating these colonies on March, 28 and every four days with different plant extract gradually decreased the rate of sealed worker brood infestation with this mite to reach the lowest infestation rates 5 weeks after treatment, Table (1). The highest reduction percentage could be applied for experimental colonies received Thyme which reached $61.7 \%$, followed by Fenugreek \& Santonica mixture (54.2 $\%)$, Fenugreek alone (43.4\%) and the least reduction $(37.4 \%)$ was, however, obtained after using Santonica alone.

Table1: Percentages of infestation with Varroa mite in honeybee sealed worker brood after treating the colonies with different plant extract during (March - April), 2012.

\begin{tabular}{|c|c|c|c|c|c|}
\hline \multirow{2}{*}{ Inspection date } & \multicolumn{4}{|c|}{ Plant Extract } & \multirow{2}{*}{ Control } \\
\hline & Fenugreek & Santonica & Fenugreek \& Santonica & Thyme & \\
\hline $\begin{array}{l}\text { Before treat. } \\
21 / 3 / 2012\end{array}$ & $10.4 \pm 4.3$ & $10.2 \pm 3.2$ & $11.2 \pm 3.6$ & $13.1 \pm 4.8$ & $12.1 \pm 4.4$ \\
\hline $\begin{array}{l}\text { After treat. } \\
\qquad 28 / 3\end{array}$ & $9.3 \pm 3.1$ & $9.4 \pm 4.2$ & $9.8 \pm 4.6$ & $11.0 \pm 5.3$ & $12.4 \pm 4.3$ \\
\hline $4 / 4$ & $8.8 \pm 4.8$ & $9.1 \pm 4.8$ & $8.9 \pm 3.6$ & $9.9 \pm 5.1$ & $13.3 \pm 2.9$ \\
\hline $11 / 4$ & $7.7 \pm 4.5$ & $8.1 \pm 3.7$ & $8.8 \pm 4.7$ & $9.7 \pm 4.4$ & $14.1 \pm 3.3$ \\
\hline $18 / 4$ & $7.2 \pm 3.3$ & $7.4 \pm 4.5$ & $7.8 \pm 3.2$ & $8.1 \pm 2.8$ & $14.3 \pm 5.1$ \\
\hline $25 / 4$ & $6.8 \pm 2.6^{\mathbf{b}}$ & $7.3 \pm 2.4^{\mathrm{c}}$ & $5.9 \pm 2.8^{\mathrm{a}}$ & $5.8 \pm 3.1^{\mathrm{a}}$ & $13.9 \pm 5.3$ \\
\hline Reduction \% & $43.4 \%$ & $37.4 \%$ & $54.2 \%$ & $61.7 \%$ & \\
\hline F value & & & $1.81^{*}$ & & \\
\hline LSD & & & 0.41 & & \\
\hline
\end{tabular}


In spite of there was decrease in the percentages of infestation in brood cell occurred for all treatments. The analysis of variance indicated that there was no significant difference for the percentages of infestation in brood cell among colonies treated with Thyme and mixture of Fenugreek \& Santonica, but there was a significant difference between them and all other treatments especially untreated colonies.

\section{Adult infestation with $\boldsymbol{V}$. Jacobsoni}

The rate of honeybee adult infestation with Varroa mite ranged between $14.0-16.3 \%$ just before treatments, Table (2). Five weeks after treatments, the rate of infestation with Varroa mite gradually decreased as the time after treatment progressed to reach the minimum infestation rate after using Thyme which recorded (6.0\%), followed by the mixture of Fenugreek \& Santonica (7.4\%), and Fenugreek only (8.5\%). The maximum (9.4\%) was however, recorded after using Santonica alone.

Table 2: Percentages of honeybee adult workers infestation with Varroa mite after treating the colonies with different plant extract during (March - April), 2012.

\begin{tabular}{|c|c|c|c|c|c|}
\hline \multirow{2}{*}{ Inspection date } & \multicolumn{4}{|c|}{ Plant Extract } & \multirow{2}{*}{ Control } \\
\hline & Fenugreek & Santonica & Fenugreek \& Santonica & Thyme & \\
\hline $\begin{array}{l}\text { Before treat. } \\
\qquad 21 / 3 / 2012\end{array}$ & $14.0 \pm 4.8$ & $14.5 \pm 3.2$ & $16.3 \pm 4.4$ & $15.5 \pm 2.7$ & $15.8 \pm 3.6$ \\
\hline $\begin{array}{l}\text { After treat. } \\
\qquad 28 / 3\end{array}$ & $12.6 \pm 3.5$ & $13.7 \pm 4.2$ & $14.8 \pm 3.6$ & $13.3 \pm 4.7$ & $15.1 \pm 5.2$ \\
\hline $4 / 4$ & $11.9 \pm 2.9$ & $12.2 \pm 5.0$ & $13.1 \pm 3.3$ & $11.8 \pm 3.5$ & $16.4 \pm 4.6$ \\
\hline $11 / 4$ & $10.7 \pm 3.5$ & $11.5 \pm 5.1$ & $11.2 \pm 2.3$ & $9.5 \pm 3.3$ & $15.9 \pm 4.4$ \\
\hline $18 / 4$ & $10.3 \pm 2.7$ & $10.4 \pm 4.1$ & $9.1 \pm 1.9$ & $8.4 \pm 4.1$ & $16.6 \pm 3.7$ \\
\hline $25 / 4$ & $8.5 \pm 3.4^{\mathrm{c}}$ & $9.4 \pm 4.8^{\mathrm{c}}$ & $7.4 \pm 1.2^{b}$ & $6.0 \pm 3.8^{\mathrm{a}}$ & $16.9 \pm 5.5^{d}$ \\
\hline Reduction \% & $43.5 \%$ & $39.7 \%$ & $58.1 \%$ & $64 \%$ & \\
\hline F value & & & $2.471 *$ & & \\
\hline LSD & & & 0.961 & & \\
\hline
\end{tabular}

The analysis of variance for the obtained data found significant decrease in the percentages of adult infestation in colonies treated with thyme $(64 \%)$ when compared with other compounds and untreated colonies, followed by mixture of Fenugreek \& Santonica (58.1\%). Meanwhile, no significant difference was found in colonies treated with either fenugreek (43.5\%) or santonica (39.7 $\%)$.

\section{Sealed worker brood cells:}

The increase in the number of sealed worker brood in the honeybee colony is considered as good indicator for queen vitality and viability moreover, the colony strength and health. Therefore, the mean numbers of sealed worker brood cells were obtained 13 days after treating the Varroa infested colonies with different compounds, Table (3). From the obtained data, the mean number of sealed brood cells before treatments ranged between 2033 - 2276 cells/colony. After treatments, this number increased gradually in treated colonies but fluctuated in untreated colonies with 13 days interval.

After three brood cycles from treatments, the number of sealed brood cells varied according to the type of compound used for controlling Varroa mites. The highest number of sealed brood cells per colony was obtained after using Thyme (4579), followed by mixture of Fenugreek \& Santonica (4181) and Fenugreek alone (3377). The least number (3058) was obtained after using Santonica alone. However, in the later case, the number of sealed brood 
cells was still significantly higher than that of the untreated colonies, which recorded (2217) cells/colony. From the analysis of variance for the obtained data, it was noticed that there are no significant difference was found in colonies treated with either Thyme or Fenugreek \& Santonica. Otherwise, no significant difference was evident in colonies treated with Fenugreek alone and Santonica alone.

Table 3: Average numbers of sealed worker brood in honeybee colonies after treating them with different plant extract during (March - April), 2012.

\begin{tabular}{|c|c|c|c|c|c|}
\hline \multirow[b]{2}{*}{ Inspection date } & \multicolumn{4}{|c|}{ Plant Extract } & \multirow[b]{2}{*}{ Control } \\
\hline & Fenugreek & Santonica & $\begin{array}{c}\text { Fenugreek \& } \\
\text { Santonica }\end{array}$ & Thyme & \\
\hline $\begin{array}{l}\text { Before treat. } \\
\qquad 21 / 3 / 2012\end{array}$ & $2276 \pm 772$ & $2104 \pm 871$ & $2082 \pm 658$ & $2188 \pm 791$ & $2033 \pm 571$ \\
\hline $\begin{array}{r}\text { After treat. } \\
3 / 4\end{array}$ & $2454 \pm 1004$ & $2320 \pm 984$ & $2536 \pm 1021$ & $2787 \pm 889$ & $1967 \pm 568$ \\
\hline $16 / 4$ & $2710 \pm 1013$ & $2633 \pm 688$ & $3110 \pm 793$ & $3354 \pm 993$ & $2014 \pm 991$ \\
\hline $29 / 4$ & $3377 \pm 887^{\mathbf{b}}$ & $3058 \pm 947^{\mathbf{b}}$ & $4181 \pm 916^{a}$ & $4579 \pm 1107^{a}$ & $2217 \pm 798^{\mathbf{c}}$ \\
\hline F value & \multicolumn{5}{|c|}{$2.546^{*}$} \\
\hline LSD & \multicolumn{5}{|c|}{751} \\
\hline
\end{tabular}

\section{Colony strength}

The number of combs covered with adult bees from both sides indicted to colony strength and therefore population density of the adult worker bees in the colony. So, data in Table (4) show that, the mean number of combs covered with adult bees in the experimental colonies before treatment ranged between 3.6 4.2 combs/colony. After treatments and as the time progress towards the end of the experiments (five weeks after treatments), an obvious and gradually increase in the number of combs covered with bees was obtained.

Table 4: Average numbers of combs covered with adult bees (colony strength) in honeybee colonies after treating them with different plant extract during (March-April), 2012.

\begin{tabular}{|c|c|c|c|c|c|}
\hline \multirow[b]{2}{*}{ Inspection date } & \multicolumn{4}{|c|}{ Plant Extract } & \multirow[b]{2}{*}{ Control } \\
\hline & Fenugreek & Santonica & $\begin{array}{c}\text { Fenugreek \& } \\
\text { Santonica }\end{array}$ & Thyme & \\
\hline $\begin{array}{l}\text { Before treat. } \\
21 / 3 / 2012 \\
\end{array}$ & $4.0 \pm 0.71$ & $4.2 \pm 0.89$ & $3.8 \pm 0.83$ & $3.6 \pm 0.90$ & $4.2 \pm 1.30$ \\
\hline $\begin{array}{l}\text { After treat. } \\
28 / 3\end{array}$ & $4.0 \pm 1.0$ & $4.2 \pm 1.3$ & $4.0 \pm 0.71$ & $3.8 \pm 0.83$ & $4.0 \pm 0.71$ \\
\hline $4 / 4$ & $4.2 \pm 0.89$ & $4.4 \pm 0.89$ & $4.2 \pm 1.30$ & $4.0 \pm 0.71$ & $3.8 \pm 0.83$ \\
\hline $11 / 4$ & $4.2 \pm 1.3$ & $4.4 \pm 1.34$ & $4.2 \pm 0.89$ & $4.4 \pm 0.90$ & $3.8 \pm 1.09$ \\
\hline $18 / 4$ & $4.6 \pm 1.14$ & $4.6 \pm 1.14$ & $4.8 \pm 0.84$ & $5.0 \pm 1.22$ & $4 . . \pm 1.0$ \\
\hline $25 / 4$ & $5.2 \pm 1.3^{\mathbf{b}}$ & $5.0 \pm 1.22^{b}$ & $5.8 \pm 1.31^{\mathrm{a}}$ & $6.2 \pm 0.84^{\mathrm{a}}$ & $3.6 \pm 0.55^{\mathrm{c}}$ \\
\hline F value & \multicolumn{5}{|c|}{$2.962 *$} \\
\hline LSD & \multicolumn{5}{|c|}{0.473} \\
\hline
\end{tabular}

At this period, the number of combs covered with adult bees reach the maximum, in spit of variation between them according to the type of compound used. The maximum number of combs/colony was obtained after using Thyme (6.2 combs), followed by Fenugreek \& Santonica mixture (5.8 combs), Fenugreek alone (5.2 combs) and Santonica (5.0 combs). This number was significantly higher than that of the corresponding number in untreated colonies where the mean number of combs/colony recorded 3.6 combs. The analysis of variance showed that there are significant difference was found between 
Thyme or mixture of Fenugreek \& Santonica in one side and Fenugreek alone or Santonica alone on the other side.

Generally, comparing the experimental colonies, which were, received different plant extract clearly show that, an increased the efficiency of any extracts used for Varroa control with the superiority of Thyme followed by mixture of Fenugreek \& Santonica, Fenugreek alone and finally Santonica alone. This extracts caused an obvious reduction of the rate of infestation either in the sealed brood or on the adult bees, and obvious increase in the number of sealed worker brood cells and, lastly, an increase in the number of combs covered from both sides with adult worker bees (colony strength) in the treated colony. This findings coincide with those of Baxter et al., 1998; Sammataro et al., 1998 and El-Bassiouny, 2003

\section{REFERNCES}

Baxter J.R.; F. Eischen, J. Pettis, W. T. Wilson and H. Shimanuki (1998). Detection of fluvalinate - resistant varroa mites in U.S honey bee. Amer. Bee J., 138:291.

Colin, M. E.; R. vandame; P. Jourdana and S. Dipasquale (1997). fluvalinate resistance of Varroa Jacobsoni oudemanns (Acari: Varroidae) in Mediterranean apiaries of France. Apidologie, 28 (6): 375-384.

Eischen, F. A. (1998):Varroa;s response to fluvalinate in the western U.S. Am. Bee. J., 138(6): 439-440

El-Bassionuny, A.M. (1998). Effect of the ectoparasitic mite, Varroa Jacobsoni on the longevity and hoarding behavior of honey bee workers. Ann. Agric., Ain shams Univ., Cairo, 43 (2):599- 605.
Elbassionuny, A.M. (2003). Maintaining and developing varroa tolerant parameters. Arab. Univ. J. Agric. Sci., 11(1): 427 - 437.

El-Bassiouny, A.M.; A.A. Gomaa; M.A. El-Banby and M.A.M. Ali (2004). Aproximated damage threshold level for varroa mite varroa destructor Inhabiting honey bee colonies. Ann. Agric. Sci., Ain shams Uni. Cairo, 49 (2): $787-792$.

Glinski, Z. and J. Jarose (1992). Varroa Jacobsoni as a carrier of bacterial infections to a recipient bee host. Apidologie, 23:25-31.

Pettis, J.; H. Shimanuki and M. Feldlaufer (1998). An assay to detect fluvalinate resistance in Varroa mites. Am. Bee J., 138(7): 538-541.

Sammataro, D. (1997). Report on parasitic honeybee mites and disease associations. Am. Bee J., 137(3): 301-303.

Sammataro, D.; H. Degrandi; G. Needham and G. Warell (1998). Some volatile oils as potential control agents for Varroa mites (Acar.: Varroidae) in honeybee colonies. Am. Bee J., 138(9): 681-685.

Shimanuki, H. and D. A. Knox (2000): Diagnosis of honey bee diseases, United States Department of Agriculture, Agriculture Research Service. Agriculture Handbook Number 690.

Shimanuki, H.; N.W.Calderon and D.A.Knox (1994). Parasitic mite syndrome. The symptoms. Am. Bee J., 134(10): 827-828.

Wallner, K. (1995). The use of varroacides and their influence on the quality of bee products. Am. Bee J., 135(12): 817-821. 


\section{ARABIC SUMMARY}

تأثير بعض المستخلصات النباتية على حلم الفاروا وأداء طوائف نحل العل

عبد اللة عبدالقادر الزروق و عادل محمد البسيونى

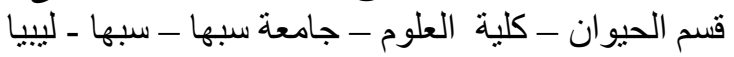

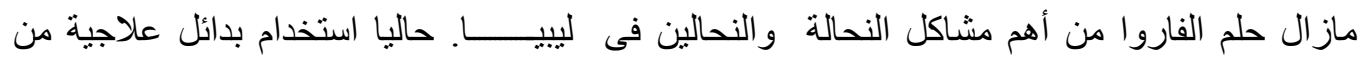

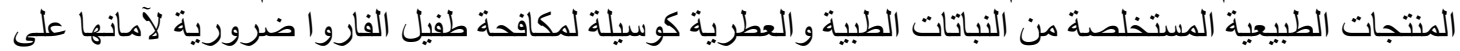

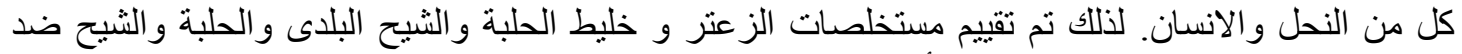

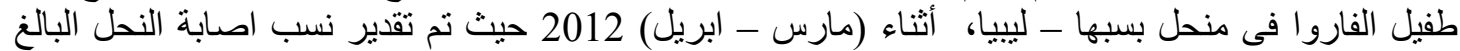
و الحضنة بالطفيل- عدد عيون الحضنة - و اعداد الاقر اص المغناء المغطاه بالنحل.

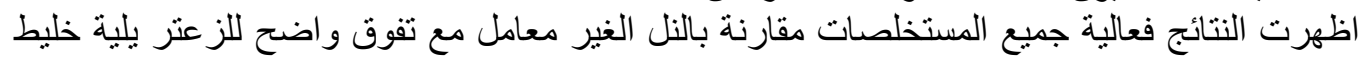

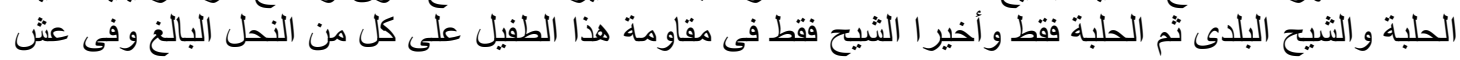

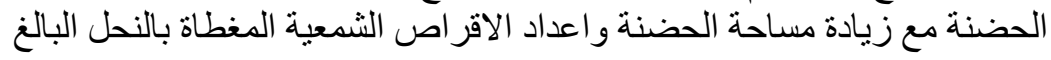

